\title{
TU/e EmonOWEN

\section{Influence of phosphate on the structure of sulfided alumina supported cobalt-molybdenum catalysts}

\section{Citation for published version (APA):}

Mangnus, P. J., van Langeveld, D., Beer, de, V. H. J., \& Moulijn, J. A. (1991). Influence of phosphate on the structure of sulfided alumina supported cobalt-molybdenum catalysts. Applied Catalysis, 68(1), 161-177. https://doi.org/10.1016/S0166-9834(00)84100-7

DOI:

10.1016/S0166-9834(00)84100-7

Document status and date:

Published: 01/01/1991

\section{Document Version:}

Publisher's PDF, also known as Version of Record (includes final page, issue and volume numbers)

\section{Please check the document version of this publication:}

- A submitted manuscript is the version of the article upon submission and before peer-review. There can be important differences between the submitted version and the official published version of record. People interested in the research are advised to contact the author for the final version of the publication, or visit the $\mathrm{DOI}$ to the publisher's website.

- The final author version and the galley proof are versions of the publication after peer review.

- The final published version features the final layout of the paper including the volume, issue and page numbers.

Link to publication

\section{General rights}

Copyright and moral rights for the publications made accessible in the public portal are retained by the authors and/or other copyright owners and it is a condition of accessing publications that users recognise and abide by the legal requirements associated with these rights.

- Users may download and print one copy of any publication from the public portal for the purpose of private study or research.

- You may not further distribute the material or use it for any profit-making activity or commercial gain

- You may freely distribute the URL identifying the publication in the public portal.

If the publication is distributed under the terms of Article 25fa of the Dutch Copyright Act, indicated by the "Taverne" license above, please follow below link for the End User Agreement:

www.tue.nl/taverne

Take down policy

If you believe that this document breaches copyright please contact us at:

openaccess@tue.nl

providing details and we will investigate your claim. 


\title{
Influence of phosphate on the structure of sulfided alumina supported cobalt-molybdenum catalysts
}

\author{
P.J. Mangnus* and A.D. van Langeveld
}

Institute of Chemical Technology, University of Amsterdam, Nieuwe Achtergracht 166 , 1018 WV Amsterdam (The Netherlands)

\section{V.H.J. de Beer}

Laboratory for Inorganic Chemistry and Catalysis, Eindhoven University of Technology, P.O. Box 513, 5600 MB Eindhoven (The Netherlands).

and

J.A. Moulijn

Faculty of Chemical Technology and Materials Science, Delft University of Technology, Julianalaan 136, 2628 BL Delft (The Netherlands)

(Received 19 June 1990, revised manuscript received 10 September 1990)

\begin{abstract}
The influence of phosphate on the sulfiding rate of alumina-supported cobalt, molybdenum and cobalt-molybdenum catalysts has been studied by means of Temperature Programmed Sulfiding (TPS). Combination of the TPS results with recently published Temperature Programmed Reduction (TPR), Mössbauer spectrometry and nitrogen oxide adsorption measurements results in a detailed picture of the sulfidic catalyst. The sulfiding of cobalt ions in phosphorus-containing alumina-supported cobalt catalysts shifted to somewhat higher temperatures with increasing phosphorus content, most likely due to the presence of "Co-AlPO" phases. In the temperature region from $1000-1270 \mathrm{~K}$, part of the cobalt sulfide species reacted with $\mathrm{AlPO}_{4}$ to cobalt phosphides. The amount of cobalt which reduced to phosphides increased strongly with increasing phosphorus content and became about $70 \%$ of the total amount of cobalt present. The sulfiding pattern of phosphorus-containing Co-Mo/Al catalysts is only slightly influenced by increasing phosphorus content below $1000 \mathrm{~K}$. All components including the Co-Mo-O-P phase, present in the oxidic precursor, are relatively easy to sulfide. After sulfiding at $673 \mathrm{~K}$, the CoMo-S phase is most likely still to be associated with the $\mathrm{AlPO}_{4}$ species. Analogous to cobalt catalysts, the major part of the cobalt in $\mathrm{Co}-\mathrm{Mo}-\mathrm{P} / \mathrm{Al}$ catalysts ultimately reacted to cobalt phosphides above about $1000 \mathrm{~K}$. The sulfiding rate of the molybdenum ions is not changed by the presence of phosphates. $\mathrm{MoS}_{2}$ does not react with the phosphates to molybdenum phosphide probably because this reaction is thermodynamically restricted. Based on the surface structures, deduced from a combination of TPR and TPS data, the striking difference between the effect of phosphates on the hydrodenitrogenation (HDN) and on the hydrodesulphurisation (HDS) reactions is discussed.
\end{abstract}

Keywords: cobalt-molybdenum/alumina, phosphate, catalyst characterization (adsorption, Mössbauer spectroscopy, TPR, TPS), sulphiding. 


\section{INTRODUCTION}

Alumina-supported cobalt-molybdenum-sulfide, nickel-molybdenum-sulfide or nickel-tungsten-sulphide catalysts are extensively used in hydrotreating processes (HDS, HDN, HDO and HDM). Cobalt and nickel sulfides have generally been supposed to be the promoters in these catalysts. Recently more and more indications appear that cobalt and nickel sulfide species might be the active sites whereas molybdenum and tungsten should be considered as the promoters [1-3]. Ever since the introduction of hydrotreating catalysts into the oil refining industry, it has been a challenge to improve their performance. Addition of a second promoter to these catalysts is one of the ways to attain this aim. Phosphorus has been used as such for nearly forty years. Because knowledge of the structure of hydrotreating catalysts was very limited for a long period, hardly any research effort was made to understand the action of secondary promoters. As a result of the discovery of the so-called "Co-Mo-S phase" as the most active phase in cobalt-molybdenum hydrotreating catalysts by Topsøe and co-workers [4,5], understanding of the performance of these catalysts has grown enormously. Determination of the presence of various cobalt and molybdenum species on the cobalt-molybdenum catalysts [4 7] made it possible to investigate even more complicated systems, such as phosphorus-promoted systems.

Phosphorus has been reported to improve the HDS [8-15] and especially the HDN activity [16-21]. Several explanations have appeared in the literature to explain this beneficial effect on the HDS/HDN activity, e.g. increment of the metal sulfide dispersion of both cobalt/nickel and molybdenum [22-25], less coke formation due to changed acidity properties [22,25,26] and the formation of more octahedrally coordinated cobalt and nickel ions [27] which exhibit a relatively high HDS/HDN activity compared to tetrahedrally coordinated ones. These surface modifications suggest an increase in both the HDS and HDN activity but they can not account for the different effect of phosphorus on the HDS and HDN activity $[20,21]$. Recently there have been indications that the active site in a phosphorus-containing catalyst might not be identical to that in conventional hydrotreating catalysts. In a TPR study [23] of oxidic Co-Mo-P/Al catalysts, a cobalt phase was observed which was reduced at a completely different temperature to that of all other cobalt species present in conventional $\mathrm{Co}-\mathrm{Mo} / \mathrm{Al}$ catalysts. This "new phase" could be described as a phase in which cobalt is in interaction with both the $\mathrm{MoO}_{3}$ and $\mathrm{AlPO}_{4}$ structures. A similar phase was reported by Atanasova et al. [27] on $\mathrm{NiMoP}$ catalysts. Also after sulfiding, indications have been found that the HDN active phase consists of a NiMoS/CoMoS phase associated with phosphate $[20,21,28]$.

Despite the fact that these observations and suggestions form a basis to explain the different influence of phosphates on HDS and HDN, the detailed 
structure of the phosphorus-containing catalysts is still unclear. Temperature Programmed Sulfiding (TPS) can be used to acquire information on the sulfiding rate of the phosphorus-promoted catalysts and subsequently it might be possible to deduce the structure of the catalyst before and after sulfiding at 673 $\mathrm{K}$, the generally applied sulfiding temperature. It will be shown that a combination of the results of TPS and TPR [23] measurements results in detailed information about the structure of phosphorus-promoted hydrotreating catalysts after sulfiding.

\section{EXPERIMENTAL}

\section{Materials}

$\mathrm{AlPO}_{4}$ (Alpha Ventron) was used as model compound. $\left(\mathrm{NH}_{4}\right)_{6} \mathrm{Mo}_{7} \mathrm{O}_{24} \cdot 6 \mathrm{H}_{2} \mathrm{O}$ (Merck), $\mathrm{Co}\left(\mathrm{NO}_{3}\right)_{2} \cdot 6 \mathrm{H}_{2} \mathrm{O}$ (Merck), $\mathrm{H}_{3} \mathrm{PO}_{4}$ (85 wt.-\% sol. in water, Janssen Chimica), $\gamma-\mathrm{Al}_{2} \mathrm{O}_{3}$ (Ketjen 000-1.5E high purity, BET surface area $200 \mathrm{~m}^{2} / \mathrm{g}$, pore volume $0.5 \mathrm{~cm}^{3} / \mathrm{g}$, particle size $100-150 \cdot 10^{-6} \mathrm{~m}$ ).

The alumina-supported catalysts were the same as those used before [23]. All catalysts were prepared by co-impregnation of the $\gamma-\mathrm{Al}_{2} \mathrm{O}_{3}$, except the phosphorus-free cobalt-molybdenum catalyst which was prepared by sequential impregnation of molybdenum and cobalt (more details can be found in ref.

\section{TABLE 1}

Catalysts applied

\begin{tabular}{|c|c|c|c|c|c|c|}
\hline \multirow[t]{2}{*}{ Catalysts } & \multicolumn{2}{|c|}{ Cobalt content } & \multicolumn{2}{|c|}{ Molybdenum content } & \multicolumn{2}{|c|}{ Phosphorus content } \\
\hline & (wt. $-\%$ ) & $\left(\mathrm{at} / \mathrm{nm}^{2}\right)$ & (wt.- \%) & $\left(\mathrm{at} / \mathrm{nm}^{2}\right)$ & (wt.- \%) & (at $/ \mathrm{nm}^{2}$ ) \\
\hline $\mathrm{P}(4.1) / \mathrm{Al}$ & - & - & - & - & 4.1 & 4.1 \\
\hline $\mathrm{Co}(1.2) \mathrm{P}(0) / \mathrm{Al}$ & 3.0 & 1.2 & - & - & - & - \\
\hline $\mathrm{Co}(1.2) \mathrm{P}(0.4) / \mathrm{Al}$ & 3.0 & 1.2 & - & - & 0.4 & 0.4 \\
\hline $\mathrm{Co}(1.2) \mathrm{P}(0.9) / \mathrm{Al}$ & 2.8 & 1.2 & - & - & 0.9 & 0.9 \\
\hline $\mathrm{Co}(1.2) \mathrm{P}(1.7) / \mathrm{Al}$ & 2.8 & 1.2 & - & - & 1.7 & 1.7 \\
\hline $\mathrm{Co}(1.1) \mathrm{P}(4.0) / \mathrm{Al}$ & 2.5 & 1.1 & - & - & 3.9 & 4.0 \\
\hline $\mathrm{Mo}(2.0) \mathrm{P}(0) / \mathrm{Al}$ & - & - & 9.1 & 2.0 & - & - \\
\hline $\mathrm{Mo}(2.0) \mathrm{P}(0.5) / \mathrm{Al}$ & - & - & 8.8 & 2.0 & 0.4 & 0.5 \\
\hline $\mathrm{Mo}(2.1) \mathrm{P}(0.9) / \mathrm{Al}$ & - & - & 9.1 & 2.1 & 0.9 & 0.9 \\
\hline $\mathrm{Mo}(2.1) \mathrm{P}(1.9) / \mathrm{Al}$ & - & - & 9.1 & 2.1 & 1.7 & 1.9 \\
\hline $\mathrm{Mo}(2.1) \mathrm{P}(4.7) / \mathrm{Al}$ & - & - & 8.8 & 2.1 & 4.2 & 4.7 \\
\hline $\mathrm{Co}(1.3) \mathrm{Mo}(2.1) \mathrm{P}(0) / \mathrm{Al}$ & 2.8 & 1.3 & 8.8 & 2.1 & - & - \\
\hline $\mathrm{Co}(1.2) \mathrm{Mo}(2.2) \mathrm{P}(0.4) / \mathrm{Al}$ & 2.6 & 1.2 & 9.1 & 2.2 & 0.4 & 0.4 \\
\hline $\mathrm{Co}(1.2) \mathrm{Mo}(2.1) \mathrm{P}(1.0) / \mathrm{Al}$ & 2.6 & 1.2 & 9.0 & 2.1 & 0.9 & 1.0 \\
\hline $\mathrm{Co}(1.3) \mathrm{Mo}(2.2) \mathrm{P}(2.1) / \mathrm{Al}$ & 2.7 & 1.3 & 9.1 & 2.2 & 1.8 & 2.1 \\
\hline $\mathrm{Co}(1.3) \mathrm{Mo}(2.1) \mathrm{P}(4.4) / \mathrm{Al}$ & 2.7 & 1.3 & 8.7 & 2.1 & 3.8 & 4.4 \\
\hline
\end{tabular}


23). The catalysts are dried at room temperature and subsequently heated up to $773 \mathrm{~K}$.

The catalyst notation is not based on weight percentages but on the cobalt, molybdenum and phosphorus loadings in atoms per $\mathrm{nm}^{2}$. The initial surface area of the support is used for the calculations. Co(1.3) Mo(2.1) $\mathrm{P}(4.4) / \mathrm{Al}$ is an example of the catalyst notation; this is an alumina-supported catalyst $\mathrm{Al}$ which contains $1.3 \mathrm{Co}, 2.1 \mathrm{Mo}$ and $4.4 \mathrm{P}$ atoms $/ \mathrm{nm}^{2}$. All catalysts used are listed in Table 1.

TPS

A detailed description of the Temperature Programmed Sulfiding apparatus (TPS) can be found elsewhere [29,30]. The sulfiding mixture consisted of ca. $3.3 \%$ hydrogen sulfide, $28 \%$ hydrogen and $68.7 \%$ argon. The flow rate was $11 \cdot 10^{-6} \mathrm{~mol} / \mathrm{s}$. All experiments have been carried out at a heating rate of 0.167 $\mathrm{K} / \mathrm{s}$ up to $1270 \mathrm{~K}$. The hydrogen and hydrogen sulfide concentrations have been measured on-line with a thermal conductivity detector (TCD) and a UV spectrophotometer, which proved to be more accurate than a mass spectrometer which has been used previously.

RESULTS

$\mathrm{Al}_{2} \mathrm{O}_{3}$

The TPS pattern of $\mathrm{Al}_{2} \mathrm{O}_{3}$ is in good agreement with the one presented in ref. 29 , the only difference being that the hydrogen sulfide concentration is measured with a UV spectrophotometer instead of a mass spectrometer. The total hydrogen sulfide uptake, which took place over the whole temperature region, equals $0.2 \cdot 10^{-3} \mathrm{~mol} / \mathrm{g}$ at the end of the temperature programme.

$\mathrm{P}(4.1) / \mathrm{Al}, \mathrm{AlPO}$

The TPS pattern of both compounds are not shown because of their complete inertness towards hydrogen sulfide over the whole temperature region. However, a small increase of the UV signal was observed during the isothermal stage at $1270 \mathrm{~K}$. As the UV signal was continuously increasing, it cannot be ascribed to the production of hydrogen sulfide but is more likely due to the irreversible adsorption of $\mathrm{P}_{2} \mathrm{O}_{3}, \mathrm{P}_{2} \mathrm{O}_{5}$ or phosphorusoxysulfides on the UV cell. These compounds were most likely formed upon decomposition of the $\mathrm{AlPO}_{4}$ structure. In the case that the phosphorus content is less than a monolayer, the hydrogen sulfide uptake of the phosphorus containing catalyst has to be corrected for the hydrogen sulfide uptake by the uncovered $\mathrm{Al}_{2} \mathrm{O}_{3}$. In the cal- 
culations, it is assumed that phosphorus adsorbs homogeneously on the surface and that a monolayer is attained at approx. $2.3 \mathrm{at} / \mathrm{nm}^{2}[25]$.

\section{$\mathrm{Co} / \mathrm{Al}, \mathrm{Co}-\mathrm{P} / \mathrm{Al}$}

The TPS patterns of the Co-P/Al catalysts are depicted in Figs. 1 and 2 . The hydrogen sulfide signals of the Co-P/Al catalysts are depicted in Fig. 1. Fig. 2 shows both the hydrogen sulfide and hydrogen signals for the $\mathrm{Co}(1.2) \mathrm{P}(1.7) / \mathrm{Al}$ and $\mathrm{Co}(1.1) \mathrm{P}(4.0) / \mathrm{Al}$ catalysts.

Fig. 1 shows that the amount of hydrogen sulfide consumed at room temperature decreased clearly with increasing phosphorus content. However, after correction for the hydrogen sulfide uptake by uncovered $\mathrm{Al}_{2} \mathrm{O}_{3}$, the resultant hydrogen sulfide consumption decreased only slightly with increasing phosphorus content. The amount of hydrogen sulfide consumed in the temperature region from $500-1000 \mathrm{~K}$ increased slightly with increasing phosphorus content. In the temperature region from 1000-1270 K phosphorus has a marked influence, viz. a broad hydrogen sulfide production and hydrogen consumption were observed simultaneously. These two peaks increased with increasing phosphorus content (Fig. 2). The hydrogen-to-hydrogen sulfide ratio for these peaks varied from 1 for the phosphorus-free catalyst to 3.4 for the phosphoruscontaining catalyst. The sulfur-to-cobalt ratio determined at the end of the temperature programme decreased from 1.3 via 0.63 to 0.39 with increasing



Fig. 1. TPS patterns $\left(\mathrm{H}_{2}\right.$ S signals ) of Co-P/Al catalysts: (A) Co(1.2) $\mathrm{P}(0) / \mathrm{Al}$; (B) Co(1.2)P(0.9)/ $\mathrm{Al}$; (C) $\mathrm{Co}(1.2) \mathrm{P}(1.7) / \mathrm{Al}$; (D) $\mathrm{Co}(1.1) \mathrm{P}(4.0) / \mathrm{Al}$. 


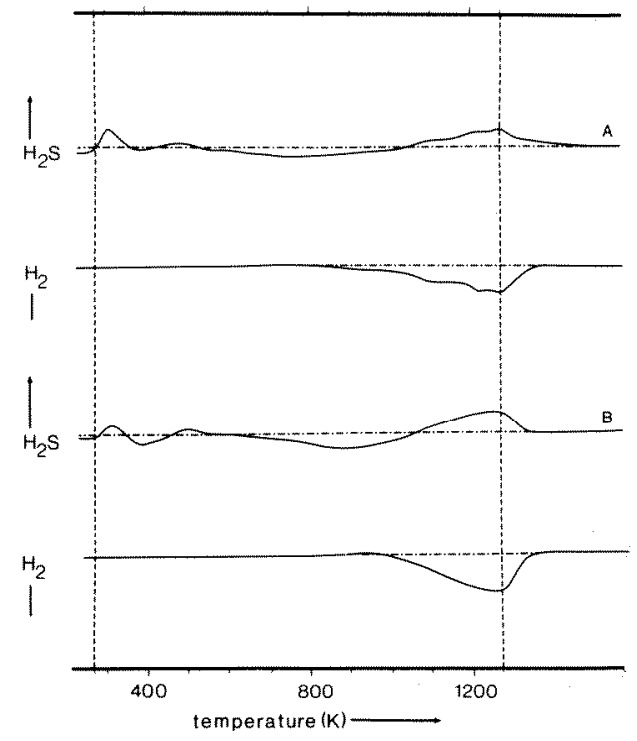

Fig. 2. TPS patterns $\left(\mathrm{H}_{2} \mathrm{~S}\right.$ signal upper curves, $\mathrm{H}_{2}$ signals lower curves) of $\mathrm{Co}-\mathrm{P} / \mathrm{Al}$ catalysts: (A) $\mathrm{Co}(1.2) \mathrm{P}(1.7) / \mathrm{Al}$; (B) Co(1.1) P (4.0)/Al.

phosphorus content. During cooling, hydrogen sulfide consumption appeared simultaneously with hydrogen production $(1070 \mathrm{~K}$, not shown $)$. The height of these peaks decreased with increasing phosphorus content and even became nearly nil for the catalyst with the highest phosphorus content.

$M o-P / A l$

The TPS patterns of Mo-P/Al catalysts are depicted in Fig. 3. They show only minor differences, if any (TPS patterns of Mo/Al catalysts were described in detail in ref. 29). Hydrogen sulfide consumption was observed already at room temperature. The colour change from white to grey-black indicates that in addition to physisorption of hydrogen sulfide sulfiding also took place. In the region from room temperature up to $500 \mathrm{~K}$ a relatively large hydrogen sulfide uptake was found while no change in the hydrogen concentration was observed. In the temperature region from $450-550 \mathrm{~K}$ hydrogen sulfide production and hydrogen consumption appeared simultaneously. Above 550 $\mathrm{K}$, the sulfiding was completed by consumption of a small amount of hydrogen sulfide. The sulfur-to-molybdenum ratio was approx. 2 at the end of the temperature program for the various molybdenum-phosphorus catalysts.

Co-Mo-P/Al

The TPS patterns of Co-Mo-P/Al catalysts are shown in Fig. 4. Both the shape of the sulfiding patterns and the amount of hydrogen sulfide consumed 


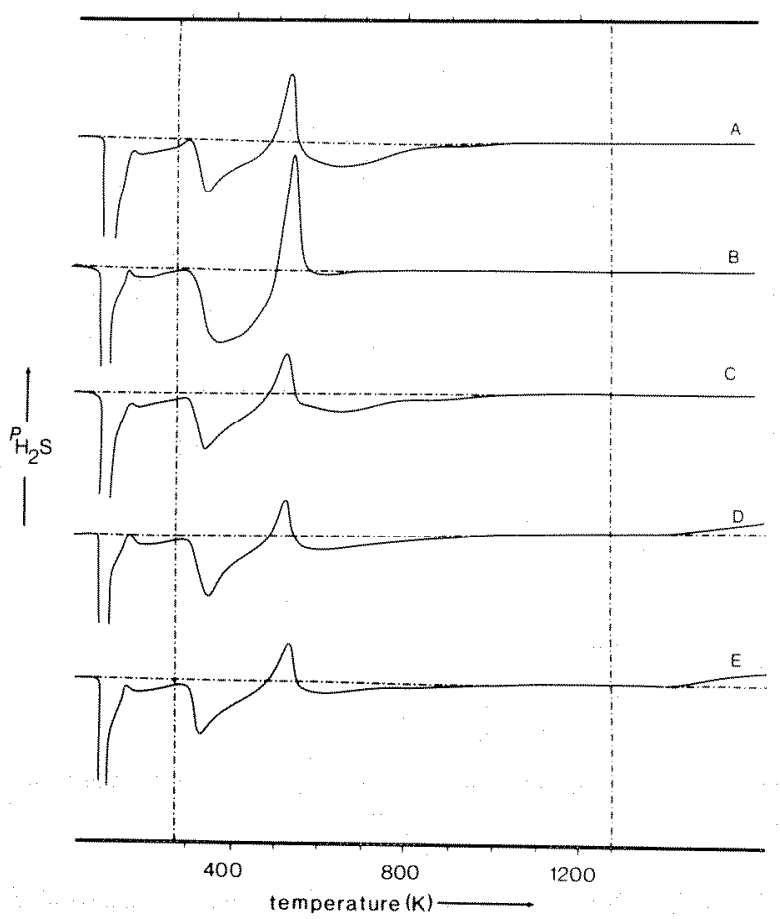

Fig. 3. TPS patterns ( $\mathrm{H}_{2} \mathrm{~S}$ signal) of $\mathrm{Mo}-\mathrm{P} / \mathrm{Al}$ catalysts: (A) $\mathrm{Mo}(2.0) \mathrm{P}(0) / \mathrm{Al}$; (B) $\mathrm{Mo}(2.0) \mathrm{P}(0.5) / \mathrm{Al}$; (C) Mo(2.1) P(0.9)/Al; (D) Mo(2.1) P(1.9)/Al; (E) Mo(2.1) P (4.7)/Al.

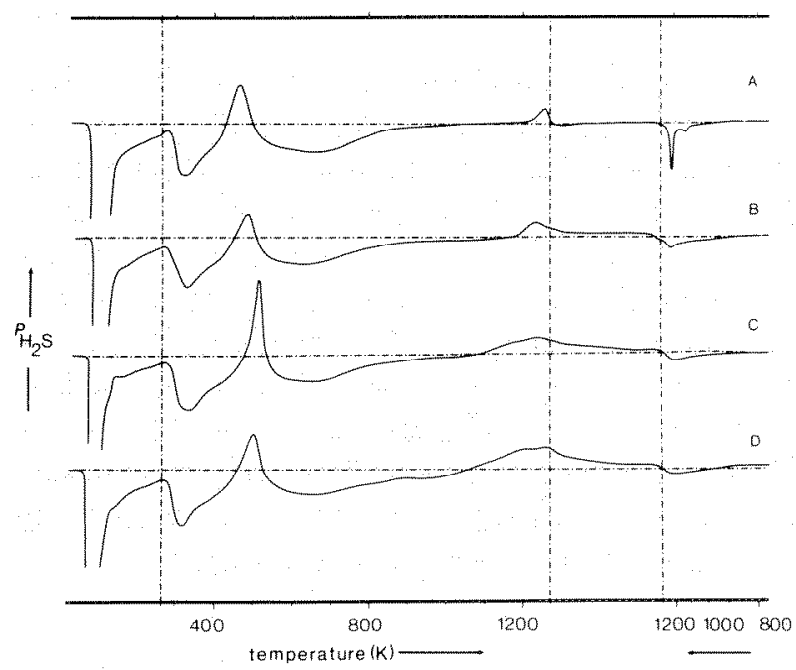

Fig. 4. TPS patterns ( $\mathrm{H}_{2} \mathrm{~S}$ signal) of Co-Mo-P/Al catalysts: (A) Co (1.3) Mo(2.1) P(0)/Al; (B) $\mathrm{Co}$ (1.2) Mo(2.1) P(1.0)/Al; (C) Co(1.3) Mo(2.2) P(2.1)/Al; (D) $\mathrm{Co}(1.3) \mathrm{Mo}(2.1) \mathrm{P}(4.4) / \mathrm{Al}$. 
up to $1000 \mathrm{~K}$ are nearly constant, irrespective of the phosphorus content. Above $1000 \mathrm{~K}$, differences due to the presence of phosphorus are observed. Analogous to the $\mathrm{Co}-\mathrm{P} / \mathrm{Al}$ samples, the $\mathrm{Co}-\mathrm{Mo}-\mathrm{P} / \mathrm{Al}$ catalysts showed a hydrogen sulfide production and hydrogen consumption peak (not shown). Because of this similar feature, it is interesting to compare this hydrogen sulfide production with the cobalt content for the $\mathrm{Co}-\mathrm{Mo}-\mathrm{P} / \mathrm{Al}$ catalysts. This hydrogen sulfide production approaches the total amount of cobalt present for the catalyst with the highest phosphorus content. The hydrogen-to-hydrogen sulfide ratio increases from 1 for the $\mathrm{Co}(1.3) \mathrm{Mo}(2.1) \mathrm{P}(0) / \mathrm{Al}$ to 3.2 for the $\mathrm{Co}(1.3) \mathrm{Mo}(2.1) \mathrm{P}(4.4) /$ Al catalysts.

\section{DISCUSSION}

$\mathrm{P}(4.1) / \mathrm{Al}, \mathrm{AlPO}_{4}$

Both model compounds were completely inactive with respect to sulfiding. In contrast with TPR [23], no reduction of the $\mathrm{AlPO}_{4}$ compounds was observed up to $1270 \mathrm{~K}$ in TPS, indicating that hydrogen sulfide retards the reduction of $\mathrm{AlPO}_{4}$. From the absence of any reduction peak, it is concluded that no $\mathrm{P}_{2} \mathrm{O}_{5}$ was present on the alumina support, because when $\mathrm{P}_{2} \mathrm{O}_{5}$ was present it would have been reduced between 800 and $1000 \mathrm{~K}$, as reported elsewhere [31].

\section{Co-P/Al}

The strong decrease in the amount of hydrogen sulfide adsorbed at room temperature (Fig. 1) with increasing phosphorus content can not directly be translated as a decreased sulfidability of the cobalt ions because of the different hydrogen sulfide adsorption properties of the phosphated alumina surfaces. Addition of phosphorus to alumina strongly decreases their hydrogen sulfide adsorption properties (not shown) and the sulfidability ultimately hecame nil for the $\mathrm{P}(4.1) / \mathrm{Al}$ catalyst. Therefore, the hydrogen sulfide uptake at room temperature has to be corrected for hydrogen sulfide adsorption on the phosphate-free alumina surface area. However, after this correction, the hydrogen sulfide consumption calculated up to $500 \mathrm{~K}$ still decreased with increasing cobalt content, which indicates that the sulfidability of cobalt decreased upon addition of phosphorus. The decrease in sulfidability can not be ascribed to an increase of the amount of $\mathrm{Co}^{2+}-\mathrm{Al}^{3+}$ spinel structures since all the $\mathrm{Co}-\mathrm{P} / \mathrm{Al}$ catalysts were prepared at the same $\mathrm{pH}$. The decrease in sulfidability is caused either by the formation of "Co-AlPO" species or by an increase of the dispersion of the cobalt species (as was observed in ref. 23). An explanation on the basis of the formation of Co-AlPO ${ }_{4}$ species is preferred to an increase in the cobalt dispersion because the presence of these species was suggested on the 
basis of TPR measurements [23]. This is further supported by TPS of carbon supported cobalt-phosphorus catalysts which showed that cobalt ions surrounded by $\mathrm{P}_{2} \mathrm{O}_{5}$ tetrahedra can be extremely difficult to sulfide.

The cobalt species which are sulfided in the high temperature region for the phosphorus-free catalysts are most likely surface tetrahedral and sub-surface $\mathrm{Co}^{2+}$ ions as discussed by Arnoldy et al. [29]. For the Co-P/Al catalysts a third phase might be added to these two species, viz. a "Co-AlPO ${ }_{4}$ " phase. The question arises if this cobalt phase sulfides during the temperature program up to $1270 \mathrm{~K}$. Table 2 shows that the sum of the amount of hydrogen sulfide consumed in the low and high temperature area are more or less equal to the total amount of cobalt present, showing that the major part of this cobalt phase has been sulfided below approx. $1050 \mathrm{~K}$.

In the TPS pattern of the $\mathrm{Co} / \mathrm{Al}$ catalyst, the small hydrogen sulfide production peak which occurred simultaneously with hydrogen consumption, around $1200 \mathrm{~K}$, has been ascribed to the interconversion of cobalt sulfides by Arnoldy et al. [6]. Because we are only dealing with one sulfide transformation at $1200 \mathrm{~K}$, this transformation can most likely be ascribed to the conversion of sintered microcrystalline $\mathrm{Co}_{9} \mathrm{~S}_{8}$ to $\mathrm{Co}_{4} \mathrm{~S}_{3}$. If relatively large crystallites are present, the sulfide transformations of $\mathrm{Co}_{9} \mathrm{~S}_{8}$ to $\mathrm{CoS}$ and subsequently to $\mathrm{Co}_{4} \mathrm{~S}_{3}$ can be observed [6]. On the basis of the amount of hydrogen sulfide produced going from $\mathrm{Co}_{9} \mathrm{~S}_{8}$ to $\mathrm{Co}_{4} \mathrm{~S}_{3}$, it appeared that approx. $25 \%$ of the cobalt is present as microcrystalline $\mathrm{Co}_{9} \mathrm{~S}_{8}$ at about $1200 \mathrm{~K}$. The other part is most likely present as cobalt sulfide species which are stabilised by the alumina against sintering.

The amount of hydrogen sulfide produced and hydrogen consumed above approx. $1000 \mathrm{~K}$ increased with increasing phosphorus content. However these peaks can not be ascribed to sulfide transformations as for the phosphorusfree catalyst, because of the following observations:

(1) The hydrogen sulfide-to-cobalt ratio (amount of hydrogen sulfide produced between $1000-1270 \mathrm{~K}$ divided by the total amount of cobalt) increased with the phosphorus content and became 0.7 for the catalyst with the highest phosphorus content, whereas a ratio of maximal 0.14 is expected on the basis of a sulfide transformation from $\mathrm{Co}_{9} \mathrm{~S}_{8}$ to $\mathrm{Co}_{4} \mathrm{~S}_{3}$.

(2) The hydrogen sulfide-to-hydrogen ratio is much lower than the ratio expected for sulfide transformations. This ratio should be one for a sulfide transformation [6].

(3) During cooling no sulfide transformations $\left(\mathrm{Co}_{4} \mathrm{~S}_{3} \rightarrow \mathrm{CoS} \rightarrow \mathrm{Co}_{9} \mathrm{~S}_{8}\right)$ are observed as should have been expected in the case in which $\mathrm{Co}_{4} \mathrm{~S}_{3}$ crystallites were present $[6,28]$.

The extremely low sulfur-to-cobalt ratio at $1270 \mathrm{~K}$ on the catalyst with the highest phosphorus content indicates that a non-sulfidic compound is formed, which is stable in this hydrogen sulfide-containing atmosphere. TPS of $\mathrm{Co}_{3}\left(\mathrm{PO}_{4}\right) \cdot 8 \mathrm{H}_{2} \mathrm{O}$ has shown that cobalt phosphides can be formed even in a hydrogen-hydrogen sulfide mixture [31]. Furthermore, TPS of carbon sup- 


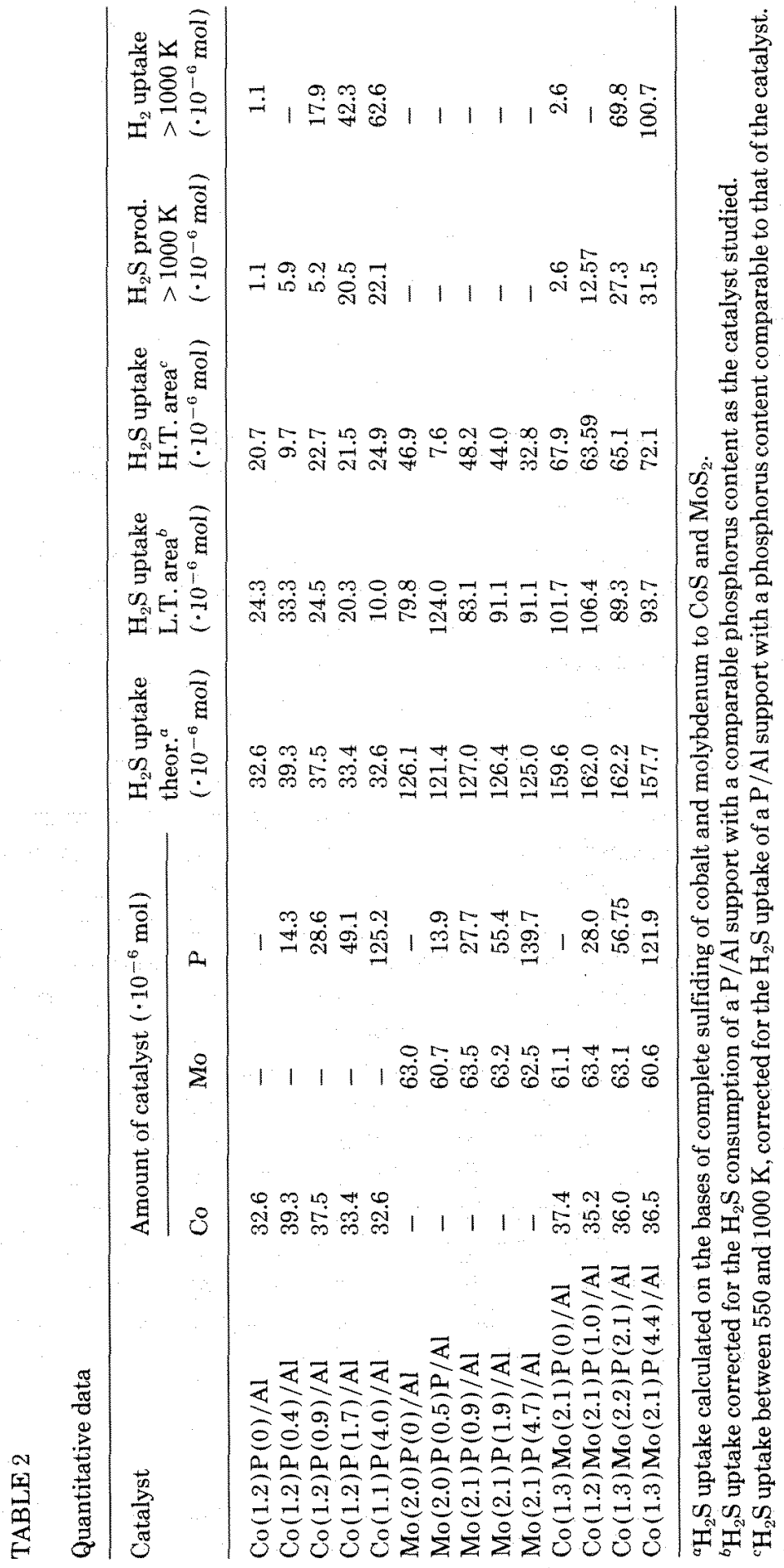




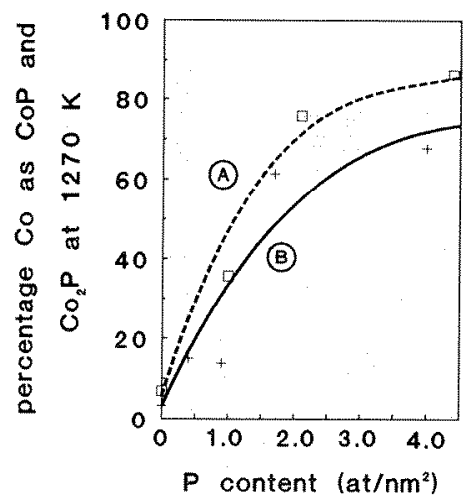

Fig. 5. The percentage of $\mathrm{CoS}$, which reacted with $\mathrm{AlPO}_{4}$ and $\mathrm{H}_{2}$ to $\mathrm{CoP}$ and $\mathrm{CO}_{2} \mathrm{P}$ in the high temperature region $(1000-1200 \mathrm{~K})$, is plotted against the phosphorus content for: $(\mathrm{A}) \mathrm{CO}-\mathrm{M}_{0}-$ $\mathrm{P} / \mathrm{Al}$ and $(\mathrm{B}) \mathrm{Co}-\mathrm{P} / \mathrm{Al}$ catalysts.

ported cobalt-phosphorus catalysts showed that $\mathrm{CoS}_{0.89}\left(=\mathrm{Co}_{9} \mathrm{~S}_{8}\right)$ can react with $\mathrm{P}_{2} \mathrm{O}_{5}$ and hydrogen to $\mathrm{CoP}$ and hydrogen sulfide above $700 \mathrm{~K}$ [30]. Analogous to this reaction on carbon, the formation of cobalt phosphide in the $\mathrm{Co}-$ $\mathrm{P} / \mathrm{Al}$ catalyst systems might be ascribed to the following reaction equations:

$$
\begin{gathered}
\mathrm{CoS}_{0.89}+\mathrm{AlPO}_{4}+3.39 \mathrm{H}_{2} \rightleftarrows 0.5 \mathrm{Al}_{2} \mathrm{O}_{3}+\mathrm{CoP}+2.5 \mathrm{H}_{2} \mathrm{O}+0.89 \mathrm{H}_{2} \mathrm{~S} \\
2 \mathrm{CoS}_{0.89}+\mathrm{AlPO}_{4}+4.28 \mathrm{H}_{2} \rightleftarrows 0.5 \mathrm{Al}_{2} \mathrm{O}_{3}+\mathrm{Co}_{2} \mathrm{P}+2.5 \mathrm{H}_{2} \mathrm{O}+1.78 \mathrm{H}_{2} \mathrm{~S}
\end{gathered}
$$

$\mathrm{Co}_{9} \mathrm{~S}_{8}$ is replaced by $\mathrm{CoS}_{0.89}$ in these equations for convenience. The for mation of $\mathrm{CoP}_{3}$ is excluded because it decomposes relatively fast above $1000 \mathrm{~K}$ [33]. In Fig. 5, the total amount of cobalt present as phosphides at $1270 \mathrm{~K}$ is divided by the total amount of cobalt present. This figure suggests that on the catalysts with a relatively high phosphorus content the major part of the cobalt was present as $\mathrm{Co}-\mathrm{AlPO}_{4}$ species before sulfiding. As solid state diffusion processes are taking place in this high-temperature region, it is not clear whether all cobalt species, which reacted to $\mathrm{CoP} / \mathrm{Co}_{2} \mathrm{P}$ have been present as $\mathrm{Co}-\mathrm{AlPO}_{4}$ species. However, the nearly quantitative formation of $\mathrm{CoP} / \mathrm{Co}_{2} \mathrm{P}$ at high phosphorus contents suggests that the major part of the cobalt ions were associated with the $\mathrm{AlPO}_{4}$ species or at least well distributed throughout the $\mathrm{AlPO}_{4}$ matrix. Thermodynamic calculations have been carried out to check whether this reaction is feasible under TPS conditions. It appears that this is possible at temperatures above $800-1000 \mathrm{~K}$. Moreover, the hydrogen-to-hydrogen sulfide ratio corresponding with reaction eqn. $1 \mathrm{a}$ and $1 \mathrm{~b}(2.4-3.8)$ is in good agreement with the hydrogen-to-hydrogen sulfide ratio measured with TPS ( \pm 3$)$.

\section{Mo-P/Al}

The sulfiding of $\mathrm{Mo} / \mathrm{Al}$ catalysts is extensively described by Arnoldy et al. [29]. The sulfiding of the $\mathrm{MoO}_{3}$ species takes place by an $\mathrm{O}-\mathrm{S}$ exchange re- 
action on the $\mathrm{Mo}^{6+}$ ions. The black colour of the catalysts at room temperature indicated that reduction of $\mathrm{Mo}^{6+}$ to $\mathrm{Mo}^{4+}$ ions has already taken place at this low temperature. From the absence of a hydrogen consumption peak in the low temperature region, it is deduced that the reduction of the molybdenum ions takes place by rupture of $\mathrm{Mo}^{6+}-\mathrm{S}$ bonds resulting in the formation of $\mathrm{Mo}^{4+}$ and elemental sulfur. The elemental sulfur reacts between 450 and $550 \mathrm{~K}$ with hydrogen to hydrogen sulfide. The sulfiding of the catalysts is completed between 550 and approx. $900 \mathrm{~K}$.

The sulfur-to-molybdenum ratio at the end of the temperature program was independent of the phosphorus content; a sulfur-to-molybdenum ratio of 2 was found for all catalysts. Therefore, it is reasonable to develop a structure model for the phosphorus-containing catalysts based on $\mathrm{MoS}_{2}$ slabs analogous to sulfided $\mathrm{MoO}_{3} / \mathrm{Al}_{2} \mathrm{O}_{3}$.

A TPR study of the oxidic Mo-P/Al catalysts revealed that a part of the molybdenum was present as ill-defined $\mathrm{Mo}-\mathrm{O}-\mathrm{P}$ phases. Evidence for these phases was also found by van Veen et al. [34]. The independence of the sulfur content and the sulfiding profiles of the Mo-P/Al catalysts with varying phosphorus-content showed that molybdenum present in a $\mathrm{Mo}-\mathrm{O}-\mathrm{P}$ phase was completely sulfidable below $800 \mathrm{~K}$. Since solid state diffusion rates are extremely slow in this temperature region, the $\mathrm{MoS}_{2}$ slabs are most likely present on the $\mathrm{AlPO}_{4}$ structures or in contact with $\mathrm{AlPO}_{4}$ through some remaining Mo-O-P bonds. Topsøe et al. [28] performed IR studies using NO as a probe to study the influence of phosphorus on the molybdenum-aluminium catalysts. Addition of phosphoric acid resulted in an upward shift of the NO-IR frequency, indicating a modification of the molybdenum-edge sites. These observations support the conclusion that we are most likely to be dealing with the molybdenum edge ions interacting with the surface through $\mathrm{Mo}-\mathrm{O}-\mathrm{P}$ rather than Mo-O-Al linkages.

In contrast with $\mathrm{Co}-\mathrm{P} / \mathrm{Al}$ and $\mathrm{Co}-\mathrm{Mo}-\mathrm{P} / \mathrm{Al}$ catalysts no hydrogen sulfide production is found in the high-temperature region. The explanation for this difference can be deduced from thermodynamics. Reaction of $\mathrm{MoS}_{2}$ to $\mathrm{MoP}$ is not expected to proceed in the same temperature region as the reaction of $\mathrm{CoS}_{0.89}$ to $\mathrm{CoP}$ since $\mathrm{MoS}_{2}$ is more stable than $\mathrm{CoS}_{0.89}$ and on the other hand MoP is less stable than CoP [33,35]. MoP is chosen as possible product instead of $\mathrm{MoP}_{2}$, because the latter decomposes in the high-temperature region [29].

Co-Mo-P/Al

TPS patterns of $\mathrm{Co} / \mathrm{Mo} / \mathrm{Al}$ catalysts have been described by Scheffer et al. [32]. In comparison with $\mathrm{Co}(1.0) / \mathrm{Al}, \mathrm{Co}(1.3) / \mathrm{Mo}(2.1) / \mathrm{Al}$ showed less sulfiding in the high temperature region, showing that less cobalt is present as surface or subsurface $\mathrm{Co}^{2+}-\mathrm{Al}^{3+}$ spinel species. The sulfiding rate of the cobalt species increased due to their interaction with the molybdenum structures. 
Clearly, the sulfiding rate of cobalt and molybdenum ions is not significantly influenced by the presence of phosphates. All catalysts are completely sulfided below $900-1000 \mathrm{~K}$. Analogous to the sulfiding patterns of the Co-P/Al catalysts, a hydrogen sulfide production peak accompanied by a hydrogen consumption peak (not shown) is found in the high temperature region. In this region the cobalt ions in the Co-Mo-P/Al catalysts react with $\mathrm{AlPO}_{4}$ and hydrogen to $\mathrm{CoP}$, hydrogen sulfide and $\mathrm{Al}_{2} \mathrm{O}_{3}$. In Fig. 5 , the percentage of cobalt that has reacted to $\mathrm{CoP}$ is plotted against the phosphorus content. For the catalyst with the highest phosphorus content, the amount of hydrogen sulfide produced approaches the theoretical maximum amount of cobalt sulfide present on the support. Therefore nearly all the cobalt sulfide formed in the lower temperature region react with $\mathrm{AlPO}_{4}$ to $\mathrm{CoP}$ and/or $\mathrm{Co}_{2} \mathrm{P}$ (according to eqns. $1 \mathrm{a}$ and $1 \mathrm{~b}$ ). The disappearance of nearly all the CoS species at $1000 \mathrm{~K}$, upon increasing phosphorus content, is confirmed by the disappearance of the sulfide transformations during cooling (Fig. 4). At a comparable phosphorus content (Fig. 5), the amount of $\mathrm{CoP}$ formed on the $\mathrm{Co}-\mathrm{Mo}-\mathrm{P} / \mathrm{Al}$ catalyst is higher than on a $\mathrm{Co}-\mathrm{P} / \mathrm{Al}$ catalyst. This indicates that the amount of cobalt ions associated with $\mathrm{AlPO}_{4}$ structures is larger on the $\mathrm{Co}-\mathrm{Mo}-\mathrm{P} / \mathrm{Al}$ catalysts than on the Co-P/Al catalysts. This is in agreement with TPR [23] of Co-Mo-P/ Al catalysts, with a relatively high phosphorus content, which showed that nearly all the cobalt was present as a Co-Mo-O-P phase. In contrast with the cobalt species in Co-P/Al catalysts, the sulfiding rate of the cobalt species on the Co-Mo-P/Al catalysts has not decreased upon addition of phosphates. The sulfiding rate of the cobalt ions most likely decreases with an increasing number of phosphate neighbours. As the number of phosphate neighbours of the cobalt ions in the Co-Mo-P/Al catalysts (Co-Mo-O-P phase) is smaller



Fig. 6. A model for sulfided Co-Mo-P/Al catalysts. 
than in $\mathrm{Co}-\mathrm{P} / \mathrm{Al}$, no strong decrease of the sulfidibility of the cobalt species is observed.

In comparison with $\mathrm{Co}^{2+}$ ions, adsorption/reaction of phosphomolybdates complexes with the alumina support is most likely to be faster due to low $\mathrm{pH}$ of the solutions applied, and therefore resulted in a completely occupied surface layer with $\mathrm{MoO}_{3}$ and $\mathrm{AlPO}_{4}$ before the cobalt ions adsorbed. TPR and FTIR measurements [23] suggest that most of the $\mathrm{MoO}_{3}$ species were located in the vicinity of the $\mathrm{AlPO}_{4}$ species. Hence, it is plausible that adsorption of $\mathrm{Co}^{2+}$ ions resulted in the formation of a Co-Mo-O-P phase and minor amounts of other species, as reported previously [23]. Whether there is still interaction between the Co-Mo-S sites and the $\mathrm{AlPO}_{4}$ species cannot be concluded from the TPS results. Topsøe et al. [28] observed that the CoMoS Mössbauer parameters changed after addition of phosphorus to these catalysts. This observation suggests that the CoMoS sites are influenced by the $\mathrm{AlPO}_{4}$ species. Based on these results a model of the catalyst after sulfiding at $673 \mathrm{~K}$ is presented in Fig. 6 for a CoMoP/Al catalyst with a relatively high phosphorus content. In this model nearly all CoMoS sites are present near an $\mathrm{AlPO}_{4}$ phase. Since the major part of the cobalt was present in the Co-Mo-O-P phase according to TPR [23], other phases such as $\mathrm{Co}_{9} \mathrm{~S}_{8}$ and $\mathrm{Co}^{2+}$ in subsurface positions are not shown.

\section{Implications for the HDS/HDN activity}

Co-Mo/Al and $\mathrm{Ni}-\mathrm{Mo} / \mathrm{Al}$ are typically applied for HDS and HDN, respectively. Despite the fact that this study is only dealing with $\mathrm{Co}-\mathrm{Mo}-\mathrm{P} / \mathrm{Al}$ catalysts it is assumed that the structural changes due to the presence of phosphate will be more or less the same for both cobalt and nickel catalysts.

Up to now, several papers have appeared concerning the influence of phosphate on hydrotreating catalysts. Addition of phosphates to alumina supported hydrotreating catalysts results in a relatively small improvement of the HDS activity $[20,36,37]$ whereas the HDN activity increases strongly [20-22]. Various explanations have been put forward to explain the positive effect of phosphorus; these explanations can be divided into two groups. The first group deals with the number of active sites while the second group suggests an influence of phosphates on the reaction mechanism.

First group:

I Increase of the cobalt (nickel) dispersion [22,23,36].

II Increase of the $\mathrm{MoS}_{2}$ dispersion [24,25,38].

III Increase of the amount of octahedral $\mathrm{Co}^{2+}\left(\mathrm{Ni}^{2+}\right)[22,27,36]$. Second group:

IV Increase of the $\mathrm{MoS}_{2}$ stacking or increment of the amount of Co-Mo$\mathrm{S}$ (II) (Ni-Mo-S(II)) [39] 
$\mathrm{V}$ Change of the properties of the $\mathrm{Co}-\mathrm{Mo}-\mathrm{S} / \mathrm{Ni}-\mathrm{Mo}-\mathrm{S}$ sites due to an interaction with the $\mathrm{AlPO}_{4}$ phase [20-23,28].

VI Influence of phosphates on the hydrogenolysis step [22].

The different influence of phosphates on HDN and HDS can not be ascribed to the structure changes I-IV, since these changes would influence the HDS and HDN activity more or less equally.

There are several other possible explanations. It could be the result of differences, in the sequence of elementary steps, in the rate determining steps or in the interaction of the sulfur and nitrogen-containing compounds with the active sites.

Relevant to the discussion is that Eijsbouts et al. [21] clearly showed that the increase of the HDN activity could be ascribed to an increase in the rate of hydrogenolysis; by bringing a $\mathrm{P} / \mathrm{Al}$ catalyst in contact with a mixture of intermediates from the quinoline $\mathrm{HDN}$ reaction, they observed that the $\mathrm{P} / \mathrm{Al}$ catalyst further increased the $\mathrm{HDN}$ conversion. Hence acidic $\mathrm{AlPO}_{4}$ groups, which are situated next to the sulfided transition metals, could effectively promote the hydrogenolysis step. For low-pressure thiophene HDS the situation is different. Since no tetrahydrothiophene is observed at low pressures, hydrogenation of the thiophene ring is most likely the rate limiting step $[40,41]$ and therefore an increase in the hydrogenolysis rate will not have much effect. At high pressures, the hydrogenolysis step becomes rate limiting and, therefore under these conditions, it is easily conceivable that phosphorus increases the HDS activity. Unfortunately, most HDS tests have been carried out at $1 \cdot 10^{5}$ $\mathrm{Pa}$. The acidic phosphate groups or modified NiMoS phase will have the largest influence on strong basic nitrogen-containing intermediates such as decahydroquinoline and 1,2,3,4-tetrahydroquinoline [42], whereas the influence on the hydrogenated sulfur rings will be much smaller, due to their much weaker basic properties. Therefore, even when the hydrogenolysis step becomes rate limiting in the $\mathrm{HDS}$ reaction, $\mathrm{AlPO}_{4}$ will only have a relatively small influence on this step. Whether phosphate also influences the hydrogenation rate or not is still unclear. However, it should be noted that under industrial HDN conditions the hydrogen pressure is so high that hydrogenolysis steps will most likely be the rate limiting steps. Therefore, even if phosphates have some influence on the ring hydrogenation rate constants, this will not be very important under industrial conditions.

\section{CONCLUSIONS}

$\mathrm{AlPO}_{4}$ and phosphates on an alumina support can not be reduced or sulfided up to $1270 \mathrm{~K}$ in a hydrogen sulfide-hydrogen atmosphere.

The sulfiding rate of the Co-P/Al catalysts is slightly decreased with increasing phosphorus content most likely due to the formation of "Co-AlPO ${ }_{4}$ " 
species. Above $1000 \mathrm{~K}$ the cobalt sulfide species react with $\mathrm{AlPO}_{4}$ and hydrogen to form $\mathrm{CoP} / \mathrm{Co}_{2} \mathrm{P}, \mathrm{Al}_{2} \mathrm{O}_{3}$ and hydrogen sulfide.

Phosphorus does not have a detectable influence on the sulfiding rate of molybdenum and cobalt-molybdenum catalysts. Analogous to the cobalt ions in the $\mathrm{Co}-\mathrm{P} / \mathrm{Al}$ catalyst, the cobalt ions in the $\mathrm{Co}-\mathrm{Mo}-\mathrm{S}$ species react with adjacent $\mathrm{AlPO}_{4}$ to $\mathrm{CoP} / \mathrm{Co}_{2} \mathrm{P}$.

$\mathrm{MoS}_{2}$ does not react with $\mathrm{AlPO}_{4}$ to $\mathrm{MoP}_{x}(x=1,2)$ below $1270 \mathrm{~K}$, due to thermodynamic restrictions.

$\mathrm{MoS}_{2}$ and Co-Mo-S species are most likely affected by the $\mathrm{AlPO}_{4}$ species after the sulfiding temperatures generally applied.

The HDN activity of phosphorus-containing hydrotreating catalysts increases due to an increase of the $\mathrm{C}-\mathrm{N}$ hydrogenolysis rate. $\mathrm{AlPO}_{4}$ species which are associated with the $\mathrm{Co}-\mathrm{Mo}-\mathrm{S}$ or $\mathrm{Ni}-\mathrm{Mo}-\mathrm{S}$ sites cause this improvement.

\section{REFERENCES}

1 J.P.R. Vissers, C.K. de Groot, E.M. van Oers, V.H.J. de Beer and R. Prins, Bull. Soc. Chim. Belg., 93 (1984) 813.

2 J.P.R. Vissers, V.H.J. de Beer and R. Prins, J. Chem. Soc., Faraday Trans. I, 83 (1987) 2145.

3 V.H.J. de Beer, J.C. Duchet and R. Prins, J. Catal., 72 (1981) 369,

4 H. Topsøe, B.S. Clausen, R. Candia, C. Wivel and S. Mørup, J. Catal., 68 (1981) 433.

5 C. Wivel, R. Candia, B.S. Clausen, S. Mørup and H. Topsøe, J. Catal., 68 (1981) 453.

6 P. Arnoldy, J.L. de Booijs, B. Scheffer and J.A. Moulijn, J. Catal., 96 (1985) 122.

7 P. Arnoldy, M.C. Franken, B. Scheffer and J.A. Moulijn, J. Catal., 96 (1985) 381.

8 T.D. Nevitt, US Patent 4381993 (1983).

9 G.A. Michelson, US Patent 3749663 (1973).

10 G.A. Michelson, US Patent 3755196 (1973).

11 G.A. Michelson, US Patent 3755150 (1973).

12 G.A. Michelson, US Patent 3755148 (1973).

13 G.A. Michelson, US Patent 3749664 (1973).

14 P. Atanasova, T. Halachev, Appl. Catal., 38 (1988) 235.

15 W.S. Millman, US Patent 4392985 (1983).

16 C.W. Fitz and H.F. Rase, Ind. Chem. Prod. Res. Dev., 22 (1983) 40.

17 S.M. Brown and D.N. Wallace, US Patent 3969273 (1976).

18 J.T. Miller, Eur. Pat. 112667 (1984).

19 R.E. Tischer, N.K. Narain, G.J. Stiegel and D.L. Cillo, Ind. Eng. Chem. Res., 26 (1986) 422.

20 S. Eijsbouts, L. van Gruijthuijsen, V.H.J. de Beer and R. Prins, in M.L. Occelli and R.O. Anthony (Eds.) Advances in Hydrotreating, 1989, p. 79.

21 S. Eijsbouts, Ph.D. Thesis, Eindhoven University of Technology, Eindhoven (1989).

22 M.M. Ramirez de Agudelo and A. Morales, in M.J. Philips and M. Ternan (Eds.), Proc. 9th Int. Congress Catalysis, Calgary, The Chemical Institute of Canada, Ottawa, Vol. 1, 1988, p. 42.

23 P.J. Mangnus, J.A.R. van Veen, S. Eijsbouts, V.H.J. de Beer and J.A. Moulijn, Appl. Catal., $61(1990) 99$.

24 W.-C. Cheng and W.P. Luthra, J. Catal., 109 (1988) 163.

25 A. Moralez, M.M. Ramirez de Agudelo and F. Hernandez, Appl. Catal., 41 (1988) 261.

26 C.W. Fitz and H.F. Rase, Ind. Eng. Chem. Prod. Res. Dev., 22 (1983) 40. 
27 P. Atanasova and T. Halachev, Appl. Catal., 48 (1989) 295.

28 H. Tupsøe, B.S. Clausen, N.-Y. Topsøe and P. Zeuthen, Paper given at Catalysts in Petroleum Refining Conference, Kuwait (1989).

29 P. Arnoldy, J.A.M. van den Heijkant, G.D. de Bok and J.A. Moulijn, J. Catal., 92 (1985) 35.

30 P.J. Mangnus, B. Scheffer and J.A. Moulijn, Preprints A.C.S. Div. Petrol. Chem., 32 (1987) 329.

31 P.J. Mangnus, V.H.J. de Beer and J.A. Moulijn, Appl. Catal.

32 B. Scheffer, I.C.M. de Jonge, P. Arnoldy and J.A. Moulijn, Bull. Soc. Chim. Belg., 93 (1984) 751.

33 J.R. van Wazer, Phosphorus and its Compounds, Vol I, Interscience, New York, 1958.

34 J.A.R. van Veen, P.A.J.M. Hendriks, E.J.G.M. Romers and R.R. Andrea, J. Phys. Chem.

35 O. Kubaschewski, E.L.L. Evans, C.B. Alcock, Metallurgical Thermochemistry, 4th edn., Pergamon Press, London, 1967.

36 D. Chadwick, D.W. Aitchison, R. Badilla-Ohlbaum, L. Josefsson, in G. Poncelet, P. Grange and P.A. Jacobs (Eds.), Studies in Surface Science and Catalysis, Vol. 16, Preparation of Catalysts III, Elsevier, Amsterdam, 1983, p. 323.

37 S.M.A.M. Bouwens, V.H.J. de Beer, R. Prins, W.L.T.M. Ramselaar, E. Gerkema and A.M. van der Kraan, J. Catal., submitted for publication.

38 A. Morales and M.M. Ramirez de Agudelo, Appl. Catal., 23 (1986) 23.

39 R.A. Kemp, R.C. Ryan and J.A. Smegal, in M.J. Philips and M. Ternan (Eds.), Proc. 9th Int. Congr. on Catalysis, Calcary, The Chemical Institute of Canada, Ottawa, Vol. 1, 1988, p. 128.

40 M. Zdrazil, Appl. Catal., 4 (1982) 107.

41 H. Schulz and D-V. Do, Bull. Soc. Chim. Belg., 93 (1984) 645.

42 V. Lavopa and C.N. Satterfield, J. Catal., 110 (1988) 375. 